\title{
Long-term emissions from mechanically biologically treated waste: Influence on leachate quality - Part II
}

\author{
C Trois* and M Griffith \\ CRECHE - Centre for Research in Environmental, Coastal and Hydrological Engineering, School of Civil Engineering, \\ Survey and Construction, University of KwaZulu-Natal, Durban, South Africa
}

\begin{abstract}
Mechanical biological pretreatment of waste prior to disposal is proven to effectively reduce the long-term polluting potentials of landfilled waste. The combined effect of waste pretreatment and flushing, as is possible in landfills operated in tropical or sub-tropical countries, has the potential to further reduce the landfills' environmental impact. In this study, long-term emissions from pretreated waste were monitored in anaerobic leaching columns operated at increasing liquid-to-solid ratios. The efficiency of the pretreatment, conducted in full-scale passively aerated windrows, was assessed by comparing different treatment periods ( 8 and 16 weeks). In order to understand the influence of sorting (separated collection) on the pretreatment, the treated waste was sieved in a $50 \mathrm{~mm}$ diameter sieve and the coarse and fine fractions separately analysed in the leaching columns. The results showed that treating the waste markedly reduces the $\mathrm{COD}$ and $\mathrm{NH}_{3}-\mathrm{N}$ loadings while the coarse fractions show a greater long-term pollutant risk.
\end{abstract}

Keywords: mechanical biological waste treatment, flushing, leaching columns, bioreactor landfill, leachate

\section{Introduction}

The increase in environmental awareness and the growing focus on sustainable development are changing the way in which modern engineers deal with solid waste disposal. In South Africa, the current approach is to 'concentrate and contain' and in the case of municipal solid waste (MSW), this includes entombing a large volume of degradable organic material in sanitary landfills that may produce highly polluted leachates. Due to the long timeframes required to reach stabilisation of the waste body, the focus has shifted towards treating the problem at the source, rather than dealing with the emissions of untreated waste (Robinson, 2000; Cossu et al., 2003).

Waste pretreatment prior to disposal is gaining momentum internationally as a possible solution. The European Council Landfill Directives 1999/31/EEC (LFD) require member states to only landfill wastes that have been subjected to prior treatment (Robinson et al., 2005). Mechanical biological pretreatment (MBP), in particular, has proven to reduce the organic loading in the leachate. The effectiveness of aerobic pretreatment on the removal of long-term ammonia loadings is still not clear.

The University of KwaZulu-Natal, in collaboration with Durban's Waste Disposal Unit (Durban Solid Waste - DSW), has conducted research on the behaviour of landfill emissions under a subtropical climate since 2000. It now appears evident that high rainfalls, typical of a subtropical climate, are favourable in promoting an optimum environment for biodegradation (Bowers, 2002). In 2002, the first South African pilot project on aerobic pretreatment of waste in passively aerated windrows was initiated at the Bisasar Road Landfill site in Durban. This note reports on an aspect of this study that investigates the possibility of coupling aerobic waste pretreatment with flushing in a bioreactor landfill in order to shorten the acetogenic stage and actively remove pollutants from the leachate. Note that a detailed descrip-

* To whom all correspondence should be addressed.

용 +2731 260-3065; fax: +2731 260-1411;

e-mail:troisc@ukzn.ac.za

Received 16 October 2007; accepted in revised form 17 June 2008. tion of the methodology followed in the windrows' construction and operation, including the assessment of the treatment performance and the preliminary results of the pilot project, was presented in Griffith and Trois, 2006. In this study, long-term emissions from pretreated municipal solid waste were monitored in anaerobic leaching columns operated at increasing liquid-tosolid ratios. The efficiency of the pretreatment was assessed by comparing different treatment periods ( 8 and 16 weeks). In order to understand the influence of sorting (separated collection) on the pretreatment efficiency and the contribution of the fine fractions in the overall organic loading in the leachate, the treated waste was sieved in a $50 \mathrm{~mm}$ diameter sieve and the coarse and fine fractions separately analyzed in the leaching columns.

\section{Materials and methods}

The Dome Aeration Technology (DAT) was used for the treatment of municipal solid waste (MSW) in passively aerated open windrows set up at the Bisasar Road Landfill site in Durban (Paar et al., 1999; Mollekopf et al., 2002; Griffith and Trois, 2006; Trois and Polster, 2007; Trois et al., 2007). The pretreatment stage involved the mixing of MSW with bulky waste, comprised mostly of dry garden refuse, to maintain the high porosity required for effective aeration. The material was wetted before placement in DAT windrows which were $10 \mathrm{~m}$ wide, $30 \mathrm{~m}$ long and $2.5 \mathrm{~m}$ in height, in order to ensure 55 to $60 \%$ moisture content for optimum microbial activity (Trois et al., 2007). The waste was then aerobically composted for 8 and 16 weeks, as discussed in detail in Griffith and Trois, 2006.

Sieving the waste is employed in the MBP process both before and after the biological treatment stage in order to separate the high calorific value coarse fraction (size $>40 \mathrm{~mm}$ ) which is usually incinerated from the fine highly biodegradable material (size $<40 \mathrm{~mm}$ ) (Soyez et al., 2002; Kuehle-Weidemeier et al., 2003). A screen size of 40 to $100 \mathrm{~mm}$ is typically used; the material retained in the sieve (called upper-sieved) is generally incinerated, while the passing (called under-sieved) undergoes biological stabilisation. In this study, the screening was applied 
for a dual reason: to understand the effect that a preliminary sorting of recyclable materials (coarse fractions) from putrescibles (fine fractions) may have in the overall treatment efficiency and in the quality of the long-term emissions from landfilled treated waste. Waste was sieved in a rotating drum screen with an aperture size of $50 \mathrm{~mm}$. The ratio of the upper-sieved (coarse) to the under-sieved (fines) was approximately 1:2.5 on a dryweight basis. However, it was noted that the coarse material still contained a portion of fine particles that adhered to its surface and were not removed during the screening. The results of the physical characterisation conducted on the two fractions are presented in Table 1.

The waste samples derived from the windrows and untreated general waste collected from the Bisasar Road landfill site were characterised using standard tests on the solid material and 24 $\mathrm{h}$ leaching tests. Analyses on the solid matter included moisture content tests, total and volatile solids and static respiration index on $7 \mathrm{~d}\left(\mathrm{RI}_{7}\right) ; 24 \mathrm{~h}$ eluate tests were conducted using a liquid- tosolid ratio $\mathrm{L} / \mathrm{S}=10$, i.e. $200 \mathrm{~g}$ of solid is soaked in $2000 \mathrm{ml}$ of distilled water in an Erlenmeyer flask that is agitated for $24 \mathrm{~h}$, and the eluate produced is then filtered in a $0.45 \mu \mathrm{m}$ filter paper and analyzed for $\mathrm{pH}$, conductivity, $\mathrm{COD}, \mathrm{BOD}, \mathrm{NH}_{3}, \mathrm{NOx}$, TS and VS. The tests were conducted for a minimum of 3 repeats with analytical methods in accordance with the US Standard Methods (2004).

Fresh waste

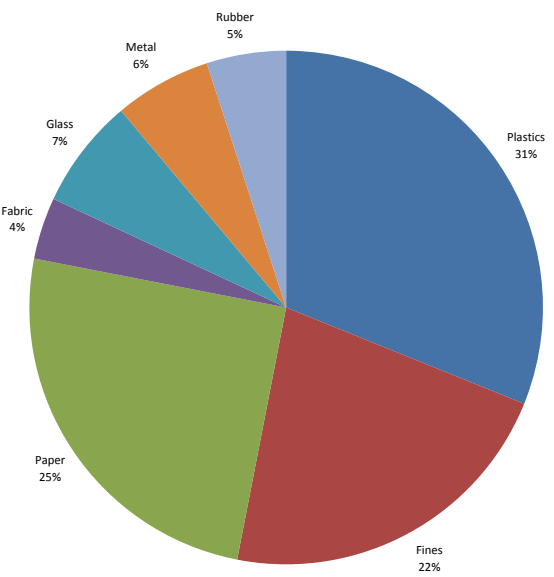

Figure 1

Composition of the untreated (fresh) waste sample

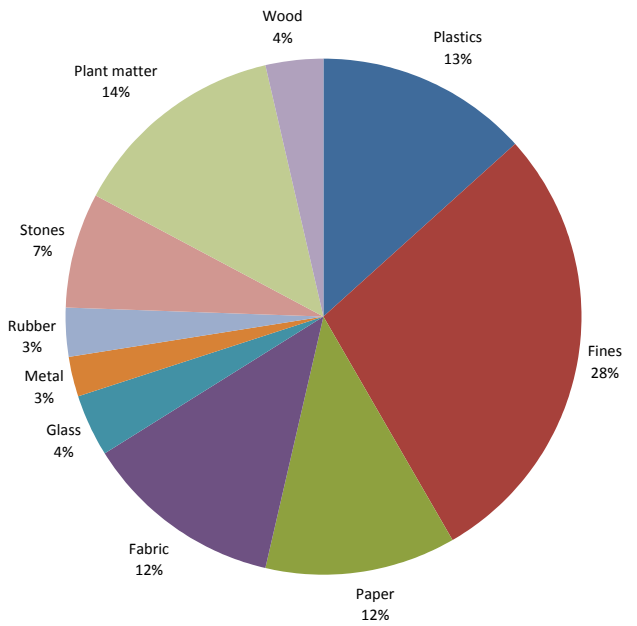

Figure 2

Composition of the treated global waste sample (before screening)

\begin{tabular}{|l|c|c|c|c|}
\hline \multicolumn{5}{|c|}{$\begin{array}{c}\text { TABLE 1 } \\
\text { Composition of the treated and untreated } \\
\text { waste samples }\end{array}$} \\
\hline $\begin{array}{l}\text { Component } \\
\text { (\% mass) }\end{array}$ & $\begin{array}{c}\text { Untreated } \\
\text { waste }\end{array}$ & $\begin{array}{c}\text { Treated } \\
\text { waste } \\
\text { global }\end{array}$ & $\begin{array}{c}\text { Treated } \\
\text { waste fine }\end{array}$ & $\begin{array}{c}\text { Treated } \\
\text { waste } \\
\text { coarse }\end{array}$ \\
\hline Plastics & 31 & 14.6 & 2.5 & 26.6 \\
\hline Fines & 22 & 31 & 54.5 & 7.6 \\
\hline Paper & 25 & 13.1 & 6.3 & 19.7 \\
\hline Fabric & 4 & 13.6 & 1.2 & 25.3 \\
\hline Glass & 7 & 4.2 & 7.7 & 0.8 \\
\hline Metal & 6 & 2.8 & 0.8 & 4.6 \\
\hline Wood & 0 & 3.9 & 0 & 7.4 \\
\hline Rubber & 5 & 3.5 & 0 & 3.8 \\
\hline Stones & 0 & 7.7 & 11.5 & 4.2 \\
\hline Plant matter & 0 & 15.1 & 15.1 & 0 \\
\hline Bone & 0 & 0 & 0.3 & 0 \\
\hline
\end{tabular}

The different component-percentages of the waste samples tested are presented in Figs. 1, 2, 3 and 4 (Marchetti, 2007).

A limitation in the eluate tests is the short timeframe of the test which does not allow for full biochemical solubilisation.

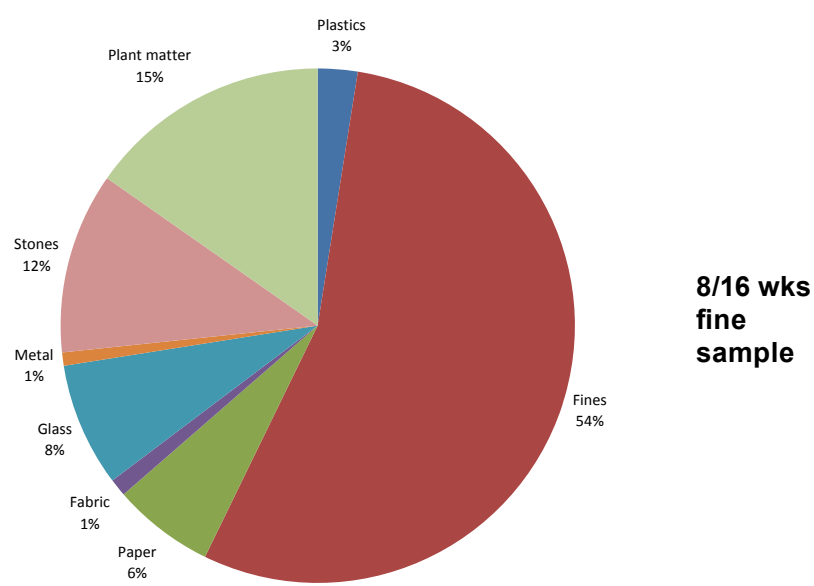

Figure 3

Composition of the lower-sieved fraction of the treated waste sample

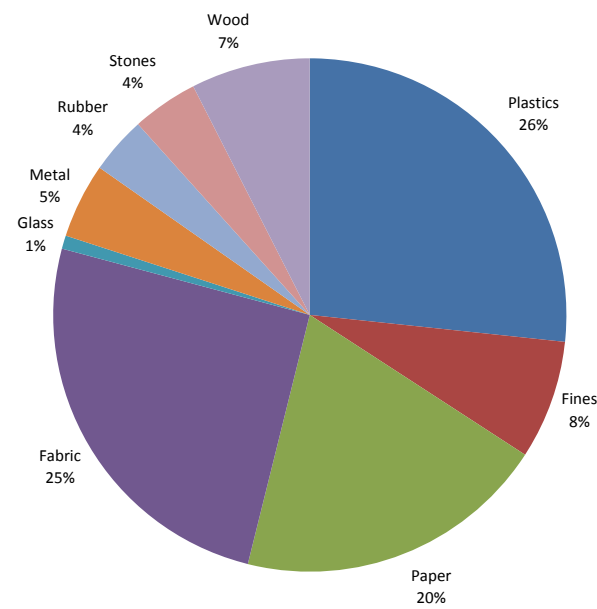

$8 / 16$ wks coarse sample

Figure 4

Composition of the upper-sieved fraction of the treated waste sample 


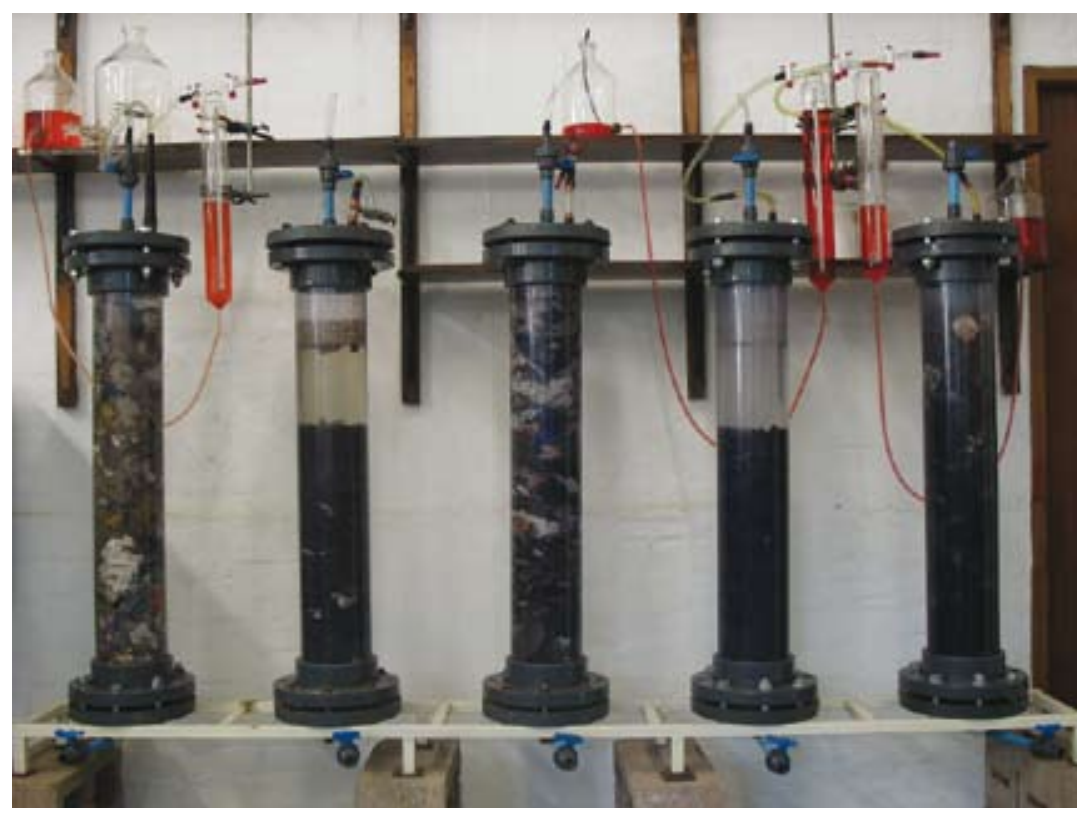

Figure 5

From left to right: Column 1: untreated waste; Column 2: under-sieved treated for 16 weeks; Column 3: over-sieved treated for 16 weeks; Column 4: under-sieved treated for 8 weeks; Column 5: over-sieved treated for 8 weeks

TABLE 2

\begin{tabular}{|l|l|l|l|l|}
\hline \multicolumn{5}{|c|}{ Column configuration } \\
\hline Column & Type of waste & $\begin{array}{l}\text { Duration of } \\
\text { treatment }\end{array}$ & Particle size & $\begin{array}{l}\text { Sample } \\
\text { denomination }\end{array}$ \\
\hline Column 1 & $\begin{array}{l}\text { Untreated } \\
\text { MSW }\end{array}$ & - & - & Control \\
\hline Column 2 & Treated MSW & 16 weeks & $<50 \mathrm{~mm}$ & Under-sieved \\
\hline Column 3 & Treated MSW & 16 weeks & $>50 \mathrm{~mm}$ & Upper-sieved \\
\hline Column 4 & Treated MSW & 8 weeks & $<50 \mathrm{~mm}$ & Under-sieved \\
\hline Column 5 & Treated MSW & 8 weeks & $>50 \mathrm{~mm}$ & Upper-sieved \\
\hline
\end{tabular}

the material deviated from the $15 \ell$ mark, the volume of gas, liquid and solid remained constant.

On a weekly basis the columns were drained and refilled with deoxygenated distilled water. This modus operandi ensured that the columns were always in contact with water, the gas volume remained constant and that the column would behave as a mixed reactor. Extracting a smaller sample of leachate may have resulted in a plug flow scenario, with the leachate removed from the bottom not representative of the column leachate as a whole. A limitation in this method is that due to the varying densities of the material, the dry masses and consequently the liquid-to-solid ratios were different for each column. Thus direct comparison of the concentrations of the parameters tested is not possible and the mass of material solubilised between each sampling step must be assessed. Table 3 shows the mass of the input materials and volumes of water added as well as the weekly flux of water.

Each column was equipped with a gas monitoring set-up employing the liquid displacement method. The biogas quality was tested weekly using an infrared gas analyzer (Geotechnical Instruments - GA 2000) which provided percentages of carbon dioxide, methane and oxygen (volume/volume in air). The leachate extracted from the columns was analysed weekly for $\mathrm{pH}$, conductivity, COD, BOD, TS, VS, $\mathrm{NH}_{4}-\mathrm{N}$ and $\mathrm{NO}_{x}-\mathrm{N}$. The tests were conducted in a minimum of three repeats following analytical methods in accordance with the US Standard

Thus leaching column tests were conducted in order to determine the leachate characteristics over a longer time frame.

The columns consisted of transparent PVC pipes, $160 \mathrm{~mm}$ in diameter and $1 \mathrm{~m}$ in length with a volume of $20 \ell$ (Fig. 5). Approximately $15 \ell$ of waste sample was weighed and inserted in the column with light compaction. The waste was then saturated by filling with distilled water to the $15 \ell$ mark, with the remaining $5 \ell$ serving as a headspace for gas analysis. During the tests, Columns 2 and 4 containing the fine fractions settled substantially while the coarse materials in Columns 1, 3 and 5 floated due to gas production (Fig. 5). Although the top level of
Methods (2004) for characterisation of water and wastewater. The columns' operation was ceased when the concentrations of parameters such as $\mathrm{NH}_{3}-\mathrm{N}$ and $\mathrm{COD}$ fell below reliable analysis range.

\section{Column processes}

In order to properly assess the evolution of the leachate quality from the columns at increasing liquid-to-solid ratios, solubilisation patterns must be analysed. The following four primary processes occur during the course of the column operation:

\begin{tabular}{|c|c|c|c|c|c|}
\hline \multicolumn{6}{|c|}{$\begin{array}{c}\text { TABLE } 3 \\
\text { Column input and operation parameters }\end{array}$} \\
\hline Parameter & Column 1 & Column 2 & Column 3 & Column 4 & Column 5 \\
\hline Waste type & Untreated & $\begin{array}{l}16 \text { weeks } \\
<50 \mathrm{~mm}\end{array}$ & $\begin{array}{l}16 \text { weeks } \\
>50 \mathrm{~mm}\end{array}$ & $\begin{array}{l}8 \text { weeks } \\
<50 \mathrm{~mm}\end{array}$ & $\begin{array}{l}8 \text { weeks } \\
<50 \mathrm{~mm}\end{array}$ \\
\hline Mass (kg) & 4.95 & 5.33 & 1.62 & 6.19 & 2.64 \\
\hline Initial water input $(\ell)$ & 9.57 & 10.14 & 12.17 & 11.83 & 10.37 \\
\hline Weekly water output $(\ell)$ & 2.56 & 4.78 & 7.93 & 5.66 & 5.94 \\
\hline Weekly L/S flux & 0.52 & 0.90 & 4.91 & 0.91 & 2.25 \\
\hline Operation time (wks) & 61 & 28 & 28 & 31 & 31 \\
\hline Final cumul. L/S ratio & 39 & 26 & 95 & 29 & 65 \\
\hline
\end{tabular}


- Solubilisation of solids into the liquid state through dissolution (Diss) and

- Hydrolysis (Hyd)

- Physical removal through the liquid flux (Phys)

- Biological conversion to biogas which is vented (Bio).

Thus the mass balance of a particular measured parameter between sampling can be expressed as follows:

\begin{tabular}{|l|c|c|c|c|c|}
\hline \multicolumn{5}{|c|}{ TABLE 4 } \\
\hline \multirow{2}{*}{ Parameter } & \multirow{2}{*}{ Untreated } & \multicolumn{2}{|c|}{$\mathbf{8}$ Weeks } & \multicolumn{2}{c|}{ 16 Weeks } \\
\cline { 3 - 6 } & & Fine & Coarse & Fine & Coarse \\
\hline $\mathrm{pH}$ & $5.3 \pm 0.2$ & $7.3 \pm 0.1$ & $6.9 \pm 0.1$ & $7.3 \pm 0.1$ & $7.0 \pm 0.1$ \\
\hline $\mathrm{Conductivity}(\mathrm{mS} / \mathrm{cm})$ & $6.2 \pm 0.01$ & $1.53 \pm 0.16$ & $1.71 \pm 0.2$ & 1.41 & 1.84 \\
\hline $\mathrm{COD}(\mathrm{mg} / \ell)$ & $7598 \pm 131$ & $1489 \pm 484$ & $1475 \pm 216$ & $3161 \pm 304$ & $3640 \pm 360$ \\
\hline $\mathrm{NH}_{3}-\mathrm{N}(\mathrm{mg} / \ell)$ & $48.5 \pm 30.5$ & $14.63 \pm 0.14$ & $10.43 \pm 0.14$ & $27.23 \pm 0.01$ & $23.3 \pm 0.01$ \\
\hline $\mathrm{NOx}-\mathrm{N}(\mathrm{mg} / \ell)$ & $18.1 \pm 8.9$ & $8.61 \pm 2.1$ & $8.12 \pm 1.6$ & $4.93 \pm 0.01$ & $5.9 \pm 0.01$ \\
\hline $\mathrm{TS}(\mathrm{g} / \ell)$ & $15.62 \pm 0.73$ & $2.64 \pm 0.79$ & $2.2 \pm 0.26$ & $7.31 \pm 0.01$ & $5.12 \pm 0.01$ \\
\hline $\mathrm{VS}(\mathrm{g} / \ell)$ & $7.13 \pm 0.29$ & $1.13 \pm 0.41$ & $0.67 \pm 0.09$ & $2.62 \pm 0.01$ & $2.8 \pm 0.01$ \\
\hline
\end{tabular}

$$
C_{i+1} * V c=C_{i}^{*} V c+\text { Diss }+ \text { Hyd }- \text { Phys }- \text { Bio }
$$

where:

$C_{i}$ is the concentration at week i

$C_{i+1}$ is the concentration the following week

$V c$ is the volume of liquid in the column

As the volume of leachate sample removed $(V l s)$ is known, the total mass physically removed (Phys) during the sampling exercise can be calculated:

$$
\text { Phys }=C_{i}^{*} V l s
$$

Thus Eq. (1) can be rewritten as follows:

$$
C_{i+1}^{*} V c=C i * V c-C i * V l s+D i s s+H y d-B i o
$$

From this formula, $C_{i+1}, C_{i}, V c$ and $V l s$ are all known while Diss, Hyd and Bio are unknown. For simplicity, these unknowns are grouped into the single parameter $\Psi$, therefore:

$$
\text { Diss }+H y d-B i o=\Psi
$$

Rearranging and grouping similar terms in Eq. (3) and dividing by the dry mass of the solid material $\left(\mathrm{M}_{\mathrm{TS}}\right)$, Eq. (3) becomes Eq. (5):

$$
\psi=\frac{C_{i+1} \cdot V_{C}}{M_{T S}}-\frac{C_{i}\left(V_{C}-V_{l s}\right)}{M_{T S}}
$$

Thus in the context of these laboratory tests, where the liquid flux is controlled, it is possible to quantify the reactions' $\Psi$. A positive $\Psi$ indicates a net solubilisation of solids into the liquid phase with a negative $\Psi$ showing a net conversion of dissolved compounds into biogas. The interpretation of this is that a material with a higher positive rate of solubilisation will cause a greater leachate load, and vice versa. The assumption in this assessment is that the solubilisation of the solids into the liquid phase is not significantly limited by their concentration.

\section{Results and discussion}

\section{Eluate tests}

The results of the 24 h eluate tests are shown in Table 4 , as an average value of three repeats and the relative standard deviation.

The untreated waste shows significantly higher values for all pollutants as well as acidic $\mathrm{pH}$. The difference between the upper-sieved and the under-sieved is less distinct and the comparable COD and volatile solids levels suggest that some organic fine particles remained attached to the upper-sieved during sieving.

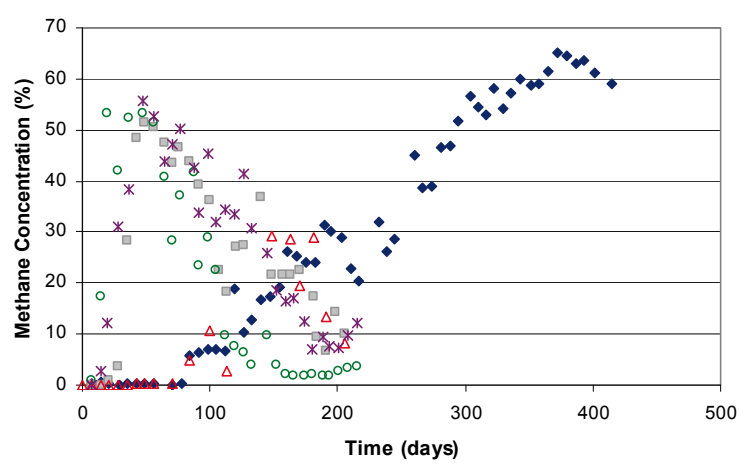
\begin{tabular}{|l|}
\hline- Col 1 \\
$\square$ Col 2 \\
$\Delta$ Col 3 \\
- Col 4 \\
$*$ Col 5 \\
\hline
\end{tabular}

Figure 6

Evolution of methane concentrations with time in the columns

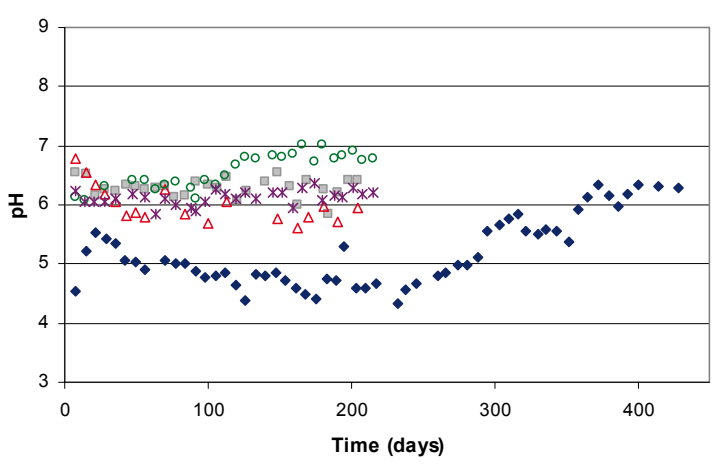

Figure 7

Evolution of $\mathrm{pH}$ with time in the effluent from the columns

\section{Column tests - Biogas and $\mathrm{pH}$}

The evolution with time of the methane concentrations from the columns and the $\mathrm{pH}$ in the leachate are presented in Figs. 6 and 7.

Column 1 experienced acidic methanogenic inhibition typical of untreated waste, with no methane generation in an acid environment at first, followed by a gradual increase for both parameters. The methane concentrations of Columns 2, 4 and 5 rise rapidly soon after commencement of the tests showing no signs of acidic inhibition, a result confirmed by the leachate $\mathrm{pH}$ which remains above 6 for both treated fractions, with particular evidence for the under-sieved Columns 2 and 4 . Methane production was initially inhibited in Column 3, due to the high porosity of the over-sieved that favoured semi-aerobic conditions before reaching methanogenesis that was achieved more rapidly by saturating the airspace above the solid waste with nitrogen gas during each irrigation, thus also reducing the negative effect of large head-spaces formed after the settlement of the fine material (Columns 2 and 4). 


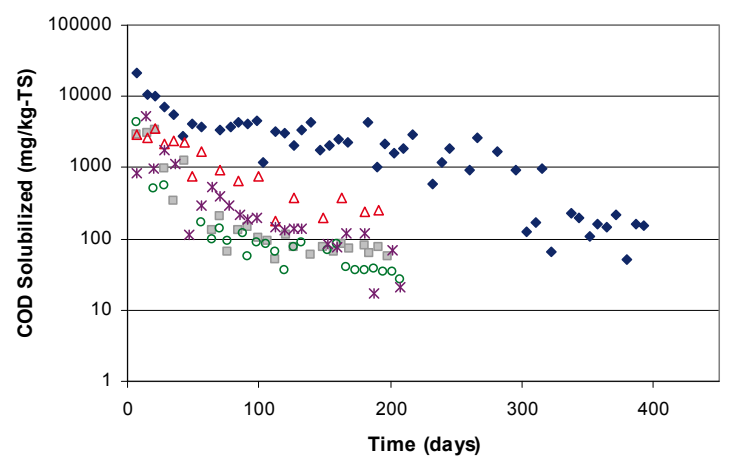

Figure 8

Evolution of $C O D$ loadings from the columns

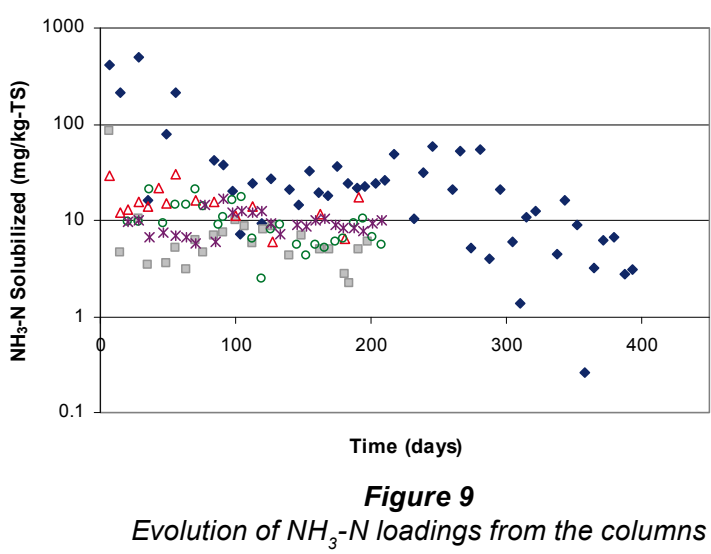

\section{Leaching processes}

The degradation processes occurring in the leaching columns were described by monitoring indicator parameters COD and ammonia. The evolution of these indicators over time in the effluents from the columns is reported in Figs. 8 and 9.

The results in Fig. 8 enable comparison of organic removal achieved with and without pretreatment, showing the benefit of the pretreatment in effectively reducing the COD concentrations in the leachate. This benefit is particularly evident for the undersieved treated material in Columns 2 and 4, if compared with the untreated global sample in Column 1. This seems to confirm the initial hypothesis that the under-sieved material contains more readily degradable fractions and that the over-sieved fraction is constituted primarily by slowly or non-degradable matter (Figs. 1 to 4 ). The almost comparable results between the behaviour of the over-sieved and the under-sieved, particularly before reaching methanogenic conditions, may be explained by an inefficient sieving technique that allowed organic fine fractions to be trapped onto the surface of the coarse material. It is interesting to note the similar behaviour for different durations of pretreatment, which indicates inefficiencies in the treatment of the 16 weeks' waste, as discussed in Griffith and Trois (2006).

Figure 9 shows the solubilisation of ammoniacal-nitrogen during the leaching process. The untreated waste (Column 1) initially releases significantly more ammoniacal nitrogen than the treated waste, with differences becoming less apparent with time. The difference between the $\mathrm{NH}_{3}-\mathrm{N}$ levels for the different treated wastes is less marked.

The cumulative pollutant load at the end of the test was calculated and a mathematical extrapolation of the solubilisation patterns was used to project the ultimate pollutant release from each column, as described under 'Column processes' above.
These results are compared to the eluate test results and are presented in Table 5.

\begin{tabular}{|c|c|c|c|}
\hline \multicolumn{4}{|c|}{$\begin{array}{c}\text { TABLE } 5 \\
\text { Cumulative COD and } \mathrm{NH}_{3}-\mathrm{N} \text { loads }\end{array}$} \\
\hline Waste type & Units & $\begin{array}{l}\text { Cumulative } \\
\text { COD }\end{array}$ & $\begin{array}{l}\text { Cumulative } \\
\mathrm{NH}_{3}-\mathrm{N}\end{array}$ \\
\hline Untreated & \multirow{15}{*}{$\mathrm{mg} / \mathrm{kg}-\mathrm{TS}$} & & \\
\hline Eluate & & 75987 & 485 \\
\hline Column 1 & & 158254 & 2097 \\
\hline 16 Weeks' Fine & & & \\
\hline Eluate & & 34230 & 11.1 \\
\hline Column 2 & & 26933 & 1002 \\
\hline 16 Weeks' Coarse & & & \\
\hline Eluate & & 34570 & 9.5 \\
\hline Column 3 & & 34481 & 428 \\
\hline 8 Weeks' Fine & & & \\
\hline Eluate & & 12430 & 14.6 \\
\hline Column 4 & & 13936 & 338 \\
\hline 8 Weeks' Coarse & & & \\
\hline Eluate & & 17390 & 10.4 \\
\hline Column 5 & & 29563 & 485 \\
\hline
\end{tabular}

The comparison between the eluate tests and the leaching columns show how the duration of the test affects the results, with higher cumulative COD loads recorded from the materials containing the slowly degradable fractions while the results from the fine material are similar to the eluate test results. The difference is more significant when considering the $\mathrm{NH}_{3}-\mathrm{N}$ results, with the longer time-frame allowing for hydrolysis of the proteinaceous material and thus a higher cumulative load of $\mathrm{NH}_{3}-\mathrm{N}$ is determined from the columns.

The eluate tests show clearly the benefit of a mechanical biological treatment prior to disposal, with a significantly lower pollutant loading measured in the treated material as compared with the untreated control. However, the small difference between the coarse and fine fractions of treated waste observed after $24 \mathrm{~h}$ of eluate tests suggests an inefficient sieving (mechanical) treatment.

Nonetheless, Table 1 and Figs. 1 to 4 show that screening the waste is an effective means of separating non-degradable (plastics) and slowly degradable (paper) recyclable materials from the waste stream. Difference in size is marked with the majority of the fine material being smaller than $10 \mathrm{~mm}$, while the majority of the coarse material is significantly greater than $50 \mathrm{~mm}$. The potential use of the finematerial as daily covershould be furtherinvestigated.

The leaching tests in columns show that the untreated waste carries a far greater pollutant load in both the short and long term than the treated fractions. Acidic inhibition was observed in the test on untreated waste, but was absent for all the treated samples. Furthermore, the untreated waste exhibits a slower leaching rate and thus presents a longer risk to the environment. The comparison between coarse and fine material shows that although the under-sieved carries a higher leaching potential in the early stages, it is the over-sieved fraction that presents a higher risk in the long term due to the slower decrease in solubilisation.

The results also confirm that the 16 weeks' treatment was less efficient than the 8 weeks' treatment to fully stabilise the waste, with the material from the latter displaying a lower pollutant loading from the eluate tests. The efficiency of the treatment process in open windrows decreases with time by increasing its 
sensitivity to negative conditions such as desiccation, and temperature variations as presented in Griffith and Trois (2006).

\section{Conclusions}

The biological aerobic treatment of MSW is effective in reducing the pollutant load of the material, with significant reductions in $\mathrm{COD}$ and $\mathrm{NH}_{3}-\mathrm{N}$ loading. The screening of the waste was successful in separating the fine fractions from what is primarily paper and plastic - materials that could be removed from the waste stream due to their potential for recycling. These fractions are also of higher calorific value and may be of benefit if waste-to-energy projects are to be considered. Furthermore, the benefit of source separation lies not only in savings of landfill airspace, but also in the reduction of long-term leachate loadings after landfilling.

\section{Acknowledgements}

The authors would like to thank the National Research Foundation (NRF) for their support through the Focus Area Programme 2007 and through the Students Scholarships Programme. Many thanks to Durban Solid Waste for technical and financial support. We would like to acknowledge the assistance of Dr Brummack and Prof. Mollekopf from Dresden University in Germany. Finally, sincere thanks to Mrs Sheila Arnold and Mr Raffaello Marchetti from the UKZN Environmental Engineering Laboratory and Master Programme.

\section{References}

BOWERS A (2002) Characterisation and Management of Landfill Emissions Under A Sub-Tropical Climate Using Full-Scale Landfill Cells. M.Sc. in Engineering Dissertation, University of Natal, Durban, South Africa.
COSSU R and ROSETTI D (2003) Pilot scale experiences with sustainable landfilling based on the PAF conceptual model. In: Proc. Sardinia 2003, $9^{\text {th }}$ Int. Waste Management and Landfill Symp. 1-5 October, Santa Margherita di Pula, Cagliari, Italy.

GRIFFITH M and TROIS C (2005) Effects of waste pre-treatment on landfill emissions under a subtropical climate. In: Proc. Sardinia 2005, $10^{\text {th }}$ Int. Waste Management and Landfill Symp. 3-7 October, Santa Margherita di Pula, Cagliari, Italy.

GRIFFITH M and TROIS C (2006) Long-term emissions from treated waste: Influence on leachate quality. Water SA 32 (3) 307-313. http:// www.wrc.org.za/downloads/watersa/2006/Jul\%2006/1971.pdf

KUEHLE-WEIDEMEIR M and DOESENS H (2003) Landfilling and properties of MBP waste. In: Proc. Sardinia 2003, $9^{\text {th }}$ Int. Waste Management and Landfill Symp. 15 October, Santa Margherita di Pula, Cagliari, Italy.

MARCHETTI R (2007) Long Term Emissions from Treated Waste: Column Studies. M.Sc. in Engineering Dissertation, University of KwaZulu-Natal, Durban, South Africa.

MOLLEKOPF N, BRUMMACK J, PAAR S and VORSTER K (2002) Use of the dome aeration technology for biochemical stabilization of waste prior to landfilling. In: Proc. Wastecon 2002, International Waste Congress and Exhibition. October 2002. Durban, South Africa.

PAAR S, BRUMMACK, J and GEMENDE B (1999) Mechanical-biological waste stabilization by the dome aeration method. Environ. Prot. Eng. 25 (3) 99.

ROBINSON HD, KNOX K, BONE, BD and PICKEN A (2005) Leachate quality from landfilled MBT waste. Waste Manage. 25 383-391.

SOYEZ K, THRAN D, VOLKER D and KOLLER M (2002) Biological pre-treatment. In: Proc. Wastecon 2002, International Waste Congress and Exhibition. October 2002. Durban, South Africa.

TROIS C and POLSTER A (2007) Effective pine bark composting with the dome aeration technology. Waste Manage. 27 (1) 96-105.

TROIS C, GRIFFITH M, BRUMMACK J and MOLLEKOPF N (2007) Introducing mechanical biological waste treatment in South Africa: A comparative study. Waste Manage. 27 (11) 1706-1714.

US STANDARD METHODS (2004) American Standard Methods for the Examination of Water and Waste Water $\left(20^{\text {th }}\right.$ edn.) American Water Works Association (AWWA). 